\title{
Understanding old-age adaptation policies in Europe: the influence of profit, principles and pressures
}

\author{
JELLE LÖSSBROEK*, BRAM LANCEE $\dagger$, TANJA VAN DER LIPPE* \\ and JOOP SCHIPPERS:
}

\begin{abstract}
To cope with an increased proportion of older workers, organisations develop oldage adaptation policies. Two strategies underlie these policies: phasing out and activating. Although the existence of these strategies is widely recognised, the reasons for their presence have rarely been explored. We identify three arguments that explain the extent to which these strategies are present: profit, principles and pressures. We hypothesise that the intensity of the phasing out strategy is higher when it is profitable and easy to replace older workers, when employer's age norms support the principle of treating older workers differently, and when external pressures are high. We also hypothesise that the intensity of the activating strategy is higher when it is profitable but hard to replace older workers, when the employer's age norms reject the principle of treating older workers differently, and when external pressures are high. We use pooled regression analysis to study imputed managerial data from 5,410 organisations in seven European countries. Results confirm the importance of external pressures for the adaptation of both strategies, and of principles for activating. Although policy feasibility is important for the adaption of both strategies, the other profit variables showed mixed results. Net benefits of older workers to the organisation are only important for phasing out, and substitutability only for activating. This paper discusses the wider implications of the study.
\end{abstract}

KEY WORDS-employability, personnel policy, older workers, organisations, age norms.

\section{Introduction}

Throughout Europe, the proportion of older $\left(\geqslant_{5} \mathrm{O}\right)$ employees is unprecedentedly high and, despite the approaching retirement of the baby-boom cohort, is projected to remain large (Streb, Voelpel and Leibold 2008;

* Department of Sociology, Utrecht University, The Netherlands.

$\dagger$ Department of Sociology, University of Amsterdam, The Netherlands.

\$ Department of Economics, Utrecht University, The Netherlands. 
Van Dalen, Henkens and Schippers 2010 $a$ ). Many European countries have consequently raised the statutory retirement age or are debating this issue, implying an even larger proportion of older workers (Fleischmann et al. 2014). Compared to their younger counterparts, older employees are generally assumed to have different strengths and weaknesses (ArmstrongStassen and Cattaneo 2010; Conen, Henkens and Schippers 2012; Jensen and Møberg 2012; Loretto and White 2006a, 2006b; Steinberg et al. 1996). Because of these marked differences, human resources (HR) policies need to take into account the age structure of the personnel. Effectively coping with a changing age structure may be crucial for firms to maintain (or even increase) employee productivity and wellbeing (Streb, Voelpel and Leibold 2008). Because employability policies primarily target younger employees, it is important to study specific old-age adaptation policies (De Vries, Gründemann and Van Vuuren 2001). It has been found that old-age adaptation policies can influence employee motivation, productivity and retirement intention, but also that the impact of focusing on older workers depends strongly on which policies are implemented (Bal, Kooij and De Jong 2013; De Grip, Fouarge and Montizaan 2015; Hewitt 2OOg).

HR policies reflect how an organisation invests in its older employees (Bal, Kooij and De Jong 2013; De Grip, Fouarge and Montizaan 2015; Kotiso and Lokhorst 2009; Van Dalen, Henkens and Schippers 2007; Ybema, Geuskens and Oude Hengel 2009). Such policies are often differentiated in two types: phasing out and activating. A phasing out strategy facilitates the employees' gradual transition into retirement and weakens the connection between employees and their work (e.g. by reducing workload). An activating strategy facilitates improving the performance of employees and strengthens the connection between the employees and their job (e.g. by training programmes).

While it is known that both strategies exist, very little is known about the extent to which either strategy is pursued, and why. There are many organisational differences in policy implementation, yet no analysis of why organisations react so differently. Age-adaptation policies are primarily studied through the profit lens (Fleischmann, Koster and Schippers 2015; Frerichs et al. 2012; Jensen and Møberg 2012; Van Dalen, Henkens and Schippers 2010a; Van Dalen, Henkens and Wang 2015). Other lines of research, however, have found that age norms and external actors (when adjusted for profit motivations) can also strongly influence an employer's decision in the hiring and retention of workers (Karpinska, Henkens and Schippers $2013 a, 2013 b$ ).

The main objective of this paper, therefore, is to understand better how the intensity of the two old-age adaptation strategies can be explained. We 
rely on three arguments to explain which policies are chosen: profits, principles and pressures. Profit considerations are based on net benefits of older workers to the organisation, the substitutability of older personnel and on the feasibility of age-adaptation policies (Conen, Henkens and Schippers 2011 ; Fleischmann, Koster and Schippers 2015; Remery et al. 2003). We refer to 'principles' when policies can be explained by age norms, such as what employers believe is a fair treatment of older workers (Oude Mulders et al. 2014; Radl 2012). Pressures refer to actors external to the decision makers, both formally (e.g. trade unions) (Van Dalen, Henkens and Wang 2015; Verma 2005) and informally (e.g. contact with employees) (Armstrong-Stassen 2008a; De Vries, Gründemann and Van Vuuren 2001). These three considerations constitute the main research question: how do profit, principles and pressures inform the strategies behind an organisation's adoption of old-age adaptation policies?

The main contribution of this paper is the simultaneous analysis of profit, principles and pressures, and the impact of their combined effects. Furthermore, we follow in the footsteps of recent work that analyses policies jointly rather than separately (Fleischmann, Koster and Schippers 2015; Van Dalen, Henkens and Wang 2015). This approach allows us to confirm empirically the theoretical distinction of phasing out and activating policies (Bal, Kooij and De Jong 2013; De Grip, Fouarge and Montizaan 2015; Kotiso and Lokhorst 2009; Van Dalen, Henkens and Schippers 2007; Ybema, Geuskens and Oude Hengel 2009). This paper thereby bridges the studies that either empirically analysed such policies separately from each other, or theoretically noted the phasing out or activating strategies underlying the policies. We have used data from Activating Senior Potential in Ageing Europe (ASPA), which was collected in 2009 from 5,410 managers in Germany, Denmark, France, Italy, the Netherlands, Poland and Sweden. Using regression analysis with country fixed effects, we have constructed independent variables for the three main arguments to predict the intensity of phasing out and activating.

\section{Old-age adaptation strategies}

Studies explaining the reasoning behind the implementation of old-age adaptation policies usually either analyse individual policies, such as training (Taylor and Walker 1998) or hiring older workers (Karpinska, Henkens and Schippers 2011), or examine multiple policies separately (Armstrong-Stassen 2008b; Armstrong-Stassen and Cattaneo 2010; Conen, Henkens and Schippers 2012; Principi, Fabbietti and Lamura 2015; Van Dalen, Henkens and Schippers 2010a; Ybema, Geuskens and Oude 
Hengel 2009). It has been argued, however, that old-age policies can be categorised within two broader strategies: phasing out and activating (Bal, Kooij and De Jong 2013; De Grip, Fouarge and Montizaan 2015; Kotiso and Lokhorst 2009; Van Dalen, Henkens and Schippers 2007; Ybema, Geuskens and Oude Hengel 2009).

The phasing out strategy is characterised by weakening the link between older workers and their job. Phasing out policies tend to 'spare' older workers, such as reducing their working hours (Ybema, Geuskens and Oude Hengel 2009), granting them additional leave or a lighter workload (Van Dalen, Henkens and Schippers 2007). If ageing makes it harder for employees to do their job, this strategy accepts this situation, and tries to make it easier. A phasing out strategy is connected to the 'early exit' discourse, in which older workers are conceptualised as less capable of keeping up with the job demands, resulting in employers decreasing the demands (Josten and Vlasblom 2015; Walker 2006). Phasing out measures make working life easier for older workers, but they also increasingly separate older workers from being a 'core worker'. Some authors distinguish three strategies with respect to older workers: accommodating, exit and activating practices (Perek-Bialas and Turek 2012; Van Dalen, Henkens and Wang 2015). Phasing out covers both the accommodating and exit practices, since the goals of those two are strongly overlapping, and the policies are alike indeed. For instance, 'exiting' part-time retirement and an 'accommodating' reduction of working hours may have different financial implications for the employees themselves. However, from an employer's perspective, these practices can have comparable consequences, such as the (partial) replacement of older workers by younger workers or the increased motivation among phased out workers. Therefore, 'exit' and 'accommodating' practices should be treated as a single dimension.

The activating strategy is characterised by strengthening the link between older workers and their job. Activating policies strive to improve the fit between work and worker, for example by changing tasks (Ybema, Geuskens and Oude Hengel 2009) or training plans (Van Dalen, Henkens and Schippers 2007; Ybema, Geuskens and Oude Hengel 2009). If ageing makes it harder for employees to do their job, this strategy challenges this situation. It tries to tackle a divergence between wage and productivity by stimulating the productivity of older workers (Van Dalen, Henkens and Schippers 2007). Policies involving job rotation can also increase productivity of colleagues by transferring knowledge between working teams (Streb, Voelpel and Leibold 2008). The strategy of activating the relationship between older workers and their organisation has its background in employment-related elements of the 'active ageing' discourse (Perek-Bialas and Turek 2012), which gained traction in the 199os. Its 
philosophy and policies focus on enabling, empowering and motivating older people, which increases their contributions to society (Frerichs et al. 2012; Walker 2006). This strategy has also been labelled 'development practices' (Van Dalen, Henkens and Wang 2015), but we prefer the word 'activating' because ergonomic measures and flexible working hours strengthen the working position of older workers without directly contributing to their development.

Phasing out and activating strategies are not mutually exclusive, and certain factors (e.g. sector, size or proportion of older workers) are associated with both. It has hence been argued that there is a single strategy of old age-related HR policies (Fleischmann, Koster and Schippers 2015). Phasing out and activating are, however, based on different logics concerning whether the link between older workers and their work should be weakened or strengthened. In line with this different logic, several organisational characteristics may have opposite effects on the two strategies, which cannot be tested if both strategies are studied jointly. Additionally, it has been argued that their consequences differ: activating policies more strongly boost work satisfaction and productivity (Bal, Kooij and De Jong 2013; De Grip, Fouarge and Montizaan 2015). The next section outlines which factors influence the intensity of each strategy (i.e. the number of related policies that are implemented).

\section{Explaining old-age adaptation policies}

In this section, we discuss a framework for three considerations affecting managers in their choice to adopt phasing out or activating old-age adaptation policies: profit, principles and pressures.

\section{Profit considerations}

Profit considerations relate to the most profitable way of dealing with older workers. Three factors can be considered relevant: net benefits of older workers to the organisation, labour substitutability, and the feasibility of adopting a particular strategy. The net benefits of older workers to the organisation are low when their costs are high or their productivity is low. Evidence of the average effect of ageing on labour costs and productivity is inconclusive (De Grip, Fouarge and Montizaan 2015; Van Dalen, Henkens and Wang 2015) and the effects of ageing may differ between different sectors and occupations. Still, employers often argue that older and younger workers have a different impact in terms of labour costs and productivity (Ebbinghaus 2006; Radl 2012; Remery et al. 2003; Van Dalen, Henkens and Schippers 
2010a). Labour substitutability concerns how hard it is to hire suitable new workers: when this is relatively easy, substitutability is high. When substitutability is low, there may be no (qualified) alternative candidates available (which could limit potential production), or finding and preparing new employees may be too expensive and time-consuming. Labour substitutability can be influenced by organisational characteristics; for instance, in a firm with higher knowledge intensity, more human capital is lost if older workers leave the firm or work fewer hours. A distinction could be made between two types of human capital: on the one hand, general innovative knowledge, which is often acquired through pre-career education, and on the other hand, firm-specific knowledge, which is often acquired through career experience (Principi, Fabbietti and Lamura 2015). As older workers are often known for their firm-specific knowledge (Karpinska, Henkens and Schippers 2011), we believe this type of knowledge is central. Substitutability can also be influenced by recruitment urgency: if the labour market is tight, or the company is expanding, maintaining personnel becomes more appealing vis-à-vis finding new workers. Both organisation knowledge intensity (Van Dalen, Henkens and Wang 2015) and labour market scarcity are known to influence HR policies (Fleischmann, Koster and Schippers 2015; Loretto and White 2006a; Lyon, Hallier and Glover 1998; De Vries, Gründemann and Van Vuuren 2001). The feasibility of policies refers to the extent to which HR policies are possible and affordable to apply. When policies are prohibitively expensive or have substantial negative externalities, employers may choose not to implement a particular strategy.

Phasing out. The intensity of the phasing out strategy may be highest when older workers (a) have low net benefits to the organisation, (b) are easily substitutable, and (c) phasing out policies are feasible. Phasing out can improve net benefits of older workers to the organisation by reducing labour costs when older employees work less, or increasing productivity when the most demanding tasks are shifted to younger workers. Phasing out policies could cost the employer money (Remery et al. 2003), but these costs may be shared with employees (e.g. partial retirement), and efficiency gains can compensate for it. Phasing out older workers and hiring new personnel, indeed, happens more often when net benefits of older workers to the organisation are lower (Remery et al. 2003) and when wages rise automatically in connection to tenure or age ('seniority wages') (Conen, Van Dalen and Henkens 2012; Ebbinghaus 2006; Van Dalen, Henkens and Wang 2015).

High substitutability of older workers supports phasing them out and attracting new employees; decisions which are often made in a context of experienced high costs to the organisation of older workers (Radl 2012; 
Remery et al. 2003; Van Dalen, Henkens and Schippers 2010a). It is easier to replace older workers with younger candidates when firm-specific organisation knowledge intensity is low (Ebbinghaus 2006), when labour is abundant (Karpinska, Henkens and Schippers 2013a; Oude Mulders et al. 2014) or if some older workers have become redundant (Loretto and White 2006a). Van Dalen, Henkens and Wang (2015) acknowledge that recruiting problems discourage part-time retirement; this mechanism plausibly also applies to comparable phasing out policies, such as reducing working hours.

The feasibility of a phasing out strategy is influenced by firm size and age distribution of the personnel. Usually, marginal costs of HR policies are lower when they apply to more workers (Fleischmann, Koster and Schippers 2015; Loretto and White 2006a). Larger organisations can more easily replace workers (Van Dalen, Henkens and Wang 2015) and are indeed known to adopt more phasing out policies (Armstrong-Stassen and Cattaneo 2010; Perek-Bialas and Turek 2012; De Vries, Gründemann and Van Vuuren 2001; Ybema, Geuskens and Oude Hengel 2009). A greater proportion of older workers has also been found to benefit phasing out policies (Armstrong-Stassen and Cattaneo 2010; Fleischmann, Koster and Schippers 2015; Van Dalen, Henkens and Wang 2015; Ybema, Geuskens and Oude Hengel 2009). We argue that this effect is curvilinear rather than linear: if the proportion of $5^{\mathrm{O}+}$ workers exceeds a certain threshold, phasing them out can be problematic for several reasons. For instance, if many older workers are excluded from the heaviest tasks or from night shifts, the number of younger workers who have to share this burden becomes too small. Alternatively, if only a small number of younger workers is present on the work floor every day, this can generate logistic issues. Excluding too large a proportion of older workers from some tasks can, indeed, be expensive (Streb, Voelpel and Leibold 2008). Finally, if older workers are perceived to be less open to being trained, these workers may flourish under phasing out measures, increasing the feasibility.

Activating. An activating strategy is most prominent when older workers (a) have low net benefits to the organisation, (b) are difficult to substitute, and (c) activating policies are feasible. Activating can improve net benefits of older workers to the organisation by increasing their human capital (Remery et al. 2003), by updating human capital that has become outdated due to technological or economic developments (Conen, Henkens and Schippers 2011; Karpinska, Henkens and Schippers 2013a) or by making better use of existing human capital. Training can increase workers' productivity in their current jobs (De Grip, Fouarge and Montizaan 2015); likewise, 
career development programmes that take advantage of older workers' increased experience can lead to a better performance and more benefits.

Low substitutability of older workers supports activating them, in contrast to phasing out and hiring replacements. Low substitutability can lead to understaffing or the need to pay higher wages to attract new workers (Remery et al. 2003), and this makes maintaining and improving current personnel more attractive. In an organisation with high knowledge intensity, retaining firm-specific human capital is more lucrative, and attracting good new personnel is harder. Activating policies such as training and career development can increase employees' loyalty through a positive reciprocity effect (De Grip, Fouarge and Montizaan 2015) or a desire to increase their market value (De Vries, Gründemann and Van Vuuren 2001). Indeed, a tight labour market can incentivise organisations to stimulate the labour market participation of older workers (Remery et al. 2003) contributing to less phasing out and more activating policies.

The feasibility of activating is influenced by the size and age distribution of the organisation, and by whether it is considered to be a good investment to train older workers. For the size and proportion of $5^{\text {o+ workers, the same }}$ marginal costs mechanism applies as for phasing out. Larger organisations have more HR expertise (Jensen and Møberg 2012), and shifting employees to a different job is easier if there are more posts available within an organisation (McNair, Flynn and Dutton 2007; Van Dalen, Henkens and Wang 2015). We argue that this effect is curvilinear for activating as well: if the proportion of older workers is too high, it may become harder to transfer all older workers to a better match. For example, a firm with 40 construction workers cannot transfer two-thirds of them to supervisory positions. Lastly, if older workers are perceived to be less open to being trained, it may be considered to be not a good investment to train older workers, and this makes activating policies less feasible.

- Hypothesis 1a: In organisations where profit considerations are characterised by low net benefits of older workers to the organisation, easy substitution of older workers, and feasible policies, the intensity of the phasing out strategy is higher.

- Hypothesis 1 b: In organisations where profit considerations are characterised by low net benefits of older workers to the organisation, difficult substitution of older workers, and feasible policies, the intensity of the activating strategy is higher.

\section{Principles: age norms}

Besides profit, employers are motivated by principles: normative ideas about what behaviour is appropriate. People and organisations want to live up to 
the principles (in this case: age norms) they and their environment profess to hold (Conen et al. 2011 ; Liefbroer and Billari 2010; Neugarten, Moore and Lowe 1965; Radl 2012). Even if no external sanctions exist, norms still guide behaviour, including workplace decisions such as retiring (Billari and Liefbroer 2007; Ebbinghaus 2006; Liefbroer and Billari 2010; Radl 2012). It was recently found that age norms prescribing how to treat older workers also influence the behaviour of employers (Karpinska, Henkens and Schippers 2013a, 2013b; Oude Mulders, Henkens and Schippers 2017). In our study, two types of age norms are considered: whether younger workers 'should' be prioritised over older workers, and at what age older workers 'should' retire (Radl 2012). Both norms reflect the underlying idea that older workers should (or should not) be treated differently than younger workers, either through prioritisation or retirement.

Phasing out. A phasing out strategy is more prominent when age norms prescribe treating older workers differently than younger workers, and when retirement age norms are low. A norm of unequal treatment supports phasing out policies, whereas a norm of equal treatment discourages them by arguing that it is unfair to assign different rights and duties. Retirement age norms have been found to influence employer's support for staying on the job after retirement age (Oude Mulders et al. 2014); in the same sense, these norms are expected to influence an employer's support for phasing out before retirement age has been reached.

Activating. An activating strategy is more appropriate when age norms prescribe older and younger workers to have the same rights and duties, and retirement age norms are high. If employers hold these age norms, they believe that older workers should contribute their share to the organisation just as the younger workers should. If older workers cannot do so in their current situation, they should be reinvigorated by activating policies. A cross-country comparison tentatively supports this: British employers were more supportive of younger and older workers being comparable, and were more likely to activate; Dutch employers were less supportive, and more often phased out (Van Dalen, Henkens and Schippers 2007).

- Hypothesis 2a: In organisations where age norms support treating older and younger workers differently and retirement age norms are low, the intensity of the phasing out strategy is higher.

- Hypothesis 2b: In organisations where age norms support treating older and younger workers equally and retirement age norms are high, the intensity of the activating strategy is higher. 


\section{Pressures}

Old-age adaptation age policies can also be influenced by formal or informal pressures. In this section, we discuss the strength of these pressures; in the next, we explain why they support phasing out and activating. Formal pressure refers to other actors which can hamper implementation or abolition of age-adaptation policies. These actors can be internal, such as employee councils and local union representation (Armstrong-Stassen and Cattaneo 2010), or external, such as labour laws and a proactive foreign headquarters (for multinational organisations). These players can influence the options which are available to the management. Trade unions are central bargaining players, and since their members are primarily older workers in most Western countries (Ebbinghaus 20o6; Visser 20o6), unions tend to support their position. Dutch unions, indeed, have succeeded in including old-age adaptation policies in most 'collective labour agreements' (Schaeps 2002). In multinational organisations, headquarters often try to export HR policies to their subsidiaries abroad (Björkman and Lervik 2007). Informal pressure comes from contact between managers and their personnel. Since people spend much of their time at the workplace, there will be many social relations (Kalleberg 2009). These ties contribute to wellbeing and functioning (for an overview, see Berman, West and Richter 2002), which gives both employees and employers an active interest in maintaining them. It has indeed been found that social ties can influence timing of retirement (Lancee and Radl 2012; Vickerstaff and Cox 2005). When managers have more contact with older workers, they may be more open to their wishes. Even if initially on an ad hoc basis, successful practices may be formalised into a more structural programme (Frerichs et al. 2012), paving the way for broader policies; indeed, managers have stated that the extent to which employees ask for certain policies influences the implementation of these policies (Armstrong-Stassen 2008a; De Vries, Gründemann and Van Vuuren 2001).

Phasing out. Stronger pressures contribute to more phasing out through formal and informal channels. Unions are often the central actor exerting formal pressure on the management, and are known to advocate implementing and maintaining phasing out policies (Ebbinghaus 2oo6; Verma 2005). Establishments with foreign headquarters are expected to offer more phasing out policies due to a combination of two mechanisms. First, importing HR policies to the establishment's country can be induced by, inter alia, a desire for internal consistency (Rosenzweig and Nohria 1994), shared training or personnel rotation (O’Donnell 20oo). Second, local 


\section{Jelle Lössbroek et al.}

labour laws, conventions and labour market competition reduces the attractiveness of achieving consistency by abolishing local policies (Rosenzweig and Nohria 1994). Stronger formal pressures can, therefore, contribute to phasing out policies. Informal pressure also contributes to more phasing out. Since employees vary in their goals and aspirations, it is likely that a substantial number of older workers would prefer phasing out options. Indeed, managers have used phasing out policies as a 'reward' for loyalty (Karpinska, Henkens and Schippers 2013b). Managers will learn these desires more readily when social ties are stronger (Van Dalen, Henkens and Wang 2015), and be thus more likely to offer phasing out options.

Activating. Stronger pressures also contribute to an activating strategy. Trade unions want to strengthen the bargaining position of their members, as better trained workers are more valuable and run lower risks of being fired. Foreign headquarters are expected to increase the activating strategy in the same way as with phasing out policies (Björkman and Lervik 2007; O'Donnell 2000; Rosenzweig and Nohria 1994). Informal pressures can also increase the intensity of the activating strategy, as stronger social ties can make managers more aware of the desires and needs for training and continuous career development among older workers. Workers who explicitly state their training desire are found to be more likely to receive training (Fleischmann and Koster 2017). Alternatively, employers may grant employees ergonomic measures or career development for the employee's sake, based on personal appreciation.

- Hypothesis za: In organisations where external pressures are stronger, the intensity of the phasing out strategy is higher.

- Hypothesis $3^{\mathrm{b}}$ : In organisations where external pressures are stronger, the intensity of the activating strategy is higher.

\section{Data, operationalisation, methodology}

\section{Data}

We used data from ASPA, a managerial survey which is frequently used to study organisational policies on older workers (Conen et al. 2011). Since managers are more aware than employees of the policies in place within their organisation, these managerial data are preferable to employee data (Armstrong-Stassen and Cattaneo 2010). Only organisations with at least ten employees were sampled; therefore, the findings of this study do not extend to very small organisations. Over 80 per cent of respondents were 
managers, predominantly HR manager (3o per cent) or Chief Executive Officer/Chief Financial Officer (CEO/CFO) (28 per cent). We refer to the respondents as 'employers', even though this is technically not always the case; it is, however, common to do so in corporate surveys (Fleischmann and Koster 2017; Fleischmann, Koster and Schippers 2015; Loretto and White 2006a; Van Dalen, Henkens and Schippers 2010b), and we control for the respondent's position. Surveys containing questions related to this paper were sent out in seven European countries: Denmark, France, Germany, Italy, the Netherlands, Poland and Sweden. The number of participating organisations ranged from $5^{\text {oo }}$ in France to 1,077 in the Netherlands; our total sample size was 5,410, the average response rate of these countries was 23 per cent. In other corporate surveys, response rates are comparable, while sample sizes are generally around 1,000 or less (Armstrong-Stassen 2008a; Conen, Henkens and Schippers 2012; De Vries, Gründemann and Van Vuuren 2001; Fleischmann, Koster and Schippers 2015; Henkens 2005; Mirvis 1997; Remery et al. 2003; Van Dalen, Henkens and Schippers 2010b). To deal with missing values, the data-set was fully imputed ( 15 imputations, 30 iterations) using the MICE package in R 3.2.2 (Van Buuren and GroothuisOudshoorn 2011; Vink, Lazendic and Van Buuren 2015; Vink and Van Buuren 2013). The percentage of missing data per variable can be found in Table 1.

\section{Operationalisation}

Respondents were given a list of policies preceded by the question 'Which of the following measures regarding older workers are currently applied in your establishment?' Both the phasing out and the activating strategy are captured by five different policies. For phasing out, these are (a) part-time retirement, (b) reduction of working time before retirement, (c) possibilities of extra leave for older workers, (d) decreasing the workload for older workers, and (e) transitional retirement. ${ }^{1}$ For activating, these are (a) training plans for older workers, (b) ergonomic measures, (c) promoting internal job mobility, (d) continuous career development and (e) flexible working hours. All policies have been related to these strategies in previous studies (Bal, Kooij and De Jong 2013; De Grip, Fouarge and Montizaan 2015; Frerichs et al. 2012; Josten and Vlasblom 2015; Streb, Voelpel and Leibold 2008; Van Dalen, Henkens and Schippers 2007; Walker 2006; Ybema, Geuskens and Oude Hengel 2009) and various empirical tests confirm this classification. Reliability analysis yields Cronbach's alpha scores of 0.70 for phasing out and 0.72 for activating; Mokken scaling analysis yields Loevinger's $H$ scores of 0.36 for phasing out and 0.38 for 
T А в L E 1. Test statistics for clustering policies into two strategies

\begin{tabular}{|c|c|c|c|c|}
\hline & Mean & $\begin{array}{l}\text { Percentage } \\
\text { missing }\end{array}$ & $\begin{array}{c}\text { Loevinger's } \\
H\end{array}$ & $\begin{array}{c}\text { Alpha if } \\
\text { item deleted }\end{array}$ \\
\hline \multicolumn{5}{|l|}{ Phasing out policies ${ }^{1}$ : } \\
\hline Part-time retirement & 0.27 & 0.12 & 0.31 & 0.70 \\
\hline Reduction of working time & 0.25 & 0.12 & 0.41 & 0.64 \\
\hline Possibilities of extra leave for $5^{0+}$ & 0.21 & 0.13 & 0.39 & 0.68 \\
\hline Decreasing the workload for $5 \mathrm{O}^{\mathrm{O}}$ & 0.20 & 0.12 & 0.35 & 0.68 \\
\hline Gradual transition & 0.24 & 0.07 & 0.33 & 0.62 \\
\hline Scale & 0.23 & 0.12 & 0.36 & $0.72^{2}$ \\
\hline \multicolumn{5}{|l|}{ Activating policies ${ }^{3}$ : } \\
\hline Training plans for $5^{\mathrm{O}+}$ & 0.22 & 0.12 & 0.32 & 0.69 \\
\hline Ergonomic measures & 0.35 & 0.12 & 0.36 & 0.65 \\
\hline Flexible working hours & 0.39 & 0.23 & 0.37 & 0.66 \\
\hline Promoting internal job mobility & 0.30 & 0.14 & 0.39 & 0.63 \\
\hline Continuous career development & 0.34 & 0.13 & 0.42 & 0.61 \\
\hline Scale & 0.32 & 0.12 & 0.38 & $0.70^{2}$ \\
\hline
\end{tabular}

Notes: 1. Polychoric principal component analysis eigenvalue: 3.11 for the first dimension and o.7o for the second. 2. Alpha of scale. 3. Polychoric principal component analysis eigenvalue: 3.0o for the first dimension and 0.73 for the second.

activating; and polychoric principal component analysis yields Kaiser's eigenvalues $>_{3}$ for the first dimension and $<0.70$ for the second dimension for both strategies. This confirms that the items indeed belong to their scales, and that the scales are both unidimensional and reliable. Scale statistics per item can be found in Table 1 . To construct the dependent variable, the sum score of the five items is taken. This means that both dependent variables are measured on a scale from o to 5 .

\section{Independent variables}

Profit considerations based on net benefits of older workers to the organisation are captured by three items. For seniority wages, respondents were asked the extent to which wages rise with tenure, on a scale of 1 (not at all) to 4 (high extent). Two items also asked the estimated impact of an average personnel age increase by five years on labour costs and on productivity, using a scale of 1 (strong decline) to 5 (strong increase). These measures have been found to reflect the actual situation in an organisation (Remery et al. 2003). Profit considerations based on substitutability are captured by three variables. The extent to which ' $[\mathrm{t}]$ he knowledge intensity in our establishment is high' ranges from 1 (completely disagree) to 5 (completely agree). Additionally, we use two dummy variables on whether employers expect the number of employees to grow or contract in the next two years (reference category: no change expected), and whether the establishment had faced recruitment issues in the last two years (1) or 
generally not (o). Profit considerations based on policy feasibility are captured by three aspects. First, the size is expressed in absolute number of employees. Second, a percentage score captures the proportion of $5^{\mathrm{O}+}$ workers (Armstrong-Stassen and Cattaneo 2010; Fleischmann, Koster and Schippers 2015; Jensen and Møberg 2012; Ybema, Geuskens and Oude Hengel 2009). To capture the theorised curvilinear relationship, we also include its quadratic function. Third, whether the respondent believes it is a better investment to train $5^{\mathrm{O}-}$ rather than $5^{\mathrm{O}+}$ employees, using a scale of 1 (completely disagree) to 5 (completely agree).

Principles are captured by three normative statements about how people should behave. The first question is about fair treatment of older workers: 'Older employees should "step aside" (take a less-demanding job) to give younger employees advancement opportunities', which was validated in the 'Beliefs about Older Workers Questionnaire' (Kluge and Krings 2008; Oude Mulders, Henkens and Schippers 2017). This item is reversed to a five-point scale ranging from 1 (strongly agree) to 5 (strongly disagree). Two open questions concern retirement age norms, of which particularly the latter is frequently used in studies on retirement age norms: 'At what age would you say a person is generally too young to retire permanently?' (Radl 2012) and 'At what age would you say a person is too old to be working 20 hours or more per week?' (Karpinska, Henkens and Schippers 2013a, 2013b; Oude Mulders, Henkens and Schippers 2017; Oude Mulders et al. 2014; Radl 2012). These items capture both the lower and upper age limit. For all three items, a higher score reflects a norm that older personnel should have the same rights and duties as their younger colleagues. Since senior managers influence each other's norms through their words and deeds, each respondent's principles likely reflect the norms and ideas held by their fellow senior colleagues (Fleischmann, Koster and Schippers 2015).

Pressures are captured by two items on formal pressures and one on informal pressures. First, respondents were asked whether trade unions influenced personnel policies, ranging from 1 (completely disagree) to 5 (completely agree). Second, foreign influences are captured by a dummy on whether an organisation is (o) national or (1) part of an international organisation or foreign owned. Informal social pressure is captured by the frequency of contact with older employees, ranging from (1) practically never to (5) daily.

\section{Control variables}

We control for several organisation and respondent characteristics. The organisation characteristics commonly included are country and sector. 
We use a dummy for each country (reference: Poland) to control for both the clustered nature of the data and different national contexts. For sector, we follow the established division between the services and trade sector and the public sector (reference category: industries and construction sector) (Jensen and Møberg 2012; Karpinska, Henkens and Schippers 2013a), as substantial sector differences in old-age adaptation policy implementation have been found (De Vries, Gründemann and Van Vuuren 2001; Hewitt 2009; Perek-Bialas and Turek 2012; Ybema, Geuskens and Oude Hengel 2009). In terms of organisational composition, we include the proportions of female, part-time, high-skilled and unskilled workers, which have yielded mixed effects in comparable studies (Jensen and Møberg 2012; Principi, Fabbietti and Lamura 2015; Remery et al. 2003; Van Dalen, Henkens and Schippers 2010a; Ybema, Geuskens and Oude Hengel 2009). Respondents were also asked to estimate how the proportion of $5^{\circ}$ + employees would change in the next five years. Lastly, several respondent characteristics were included, as there are indications that these are relevant (Principi, Fabbietti and Lamura 2015; Shore, Cleveland and Goldberg 2003). Respondents were asked to state their function (recoded to dichotomous variables for head of department, general manager, HR manager/ HR officer, administrator and other, reference category: CEO/CFO), whether their job requires an academic degree, their age and their gender.

Descriptive statistics are shown in Table 2.

\section{Methodology}

Our dependent variables are coded on five-point scales concerning the intensity of either strategy. We therefore use ordinary least squares regression analysis. Since the two dimensions are not mutually exclusive, separate models are estimated for phasing out and for activating, using a dummy variable for each country to control for the clustered nature of the data within the different countries. Following multiple imputation best practice, regression results are pooled (Van Buuren and Groothuis-Oudshoorn 2011).

\section{Results}

In our data, 613 organisations ( $11 \%)$ implemented only a phasing out strategy, 1,176 organisations ( $22 \%)$ implemented only an activating strategy, 2,501 implemented both $(46 \%)$ and 1,120 implemented neither (21\%). The intensities of the strategies are substantially correlated (Pearson correlation $=0.4^{18}$, significant at $\left.p<0.001\right)$ but essentially different. These frequencies concur with other studies (Conen, Henkens and Schippers 
TA в L E 2. Descriptive statistics

\begin{tabular}{|c|c|c|c|c|c|}
\hline Variable & Mean & SD & Minimum & Maximum & $\begin{array}{l}\text { Missing } \\
(\%)\end{array}$ \\
\hline \multicolumn{6}{|l|}{ Profit: } \\
\hline Seniority wages & 2.59 & 0.82 & 1 & 4 & 0.01 \\
\hline Ageing increases labour costs & 3.48 & 0.64 & 1 & 5 & 0.07 \\
\hline Ageing increases productivity & 2.74 & 0.63 & 1 & 5 & 0.06 \\
\hline Organisation knowledge intensity & 3.54 & 1.17 & 1 & 5 & 0.10 \\
\hline Expected size: growth & 0.54 & - & o & 1 & 0.01 \\
\hline Expected size: stays the same & 0.23 & - & o & 1 & 0.01 \\
\hline Expected size: contraction & 0.23 & - & o & 1 & 0.01 \\
\hline Recruitment problems & $0.4^{6}$ & $0.5^{\circ}$ & o & 1 & 0.01 \\
\hline Number of employees & 539.80 & $8,024.81$ & 1 & 500,000 & 0.01 \\
\hline$\% 5^{\mathrm{O}+}$ workers & 0.24 & 0.18 & o & 1 & 0.02 \\
\hline$\% 5^{\mathrm{O}+}$ workers, squared & 0.09 & 0.12 & o & 1 & 0.02 \\
\hline Better investment to train $5^{0-}$ & 2.81 & 1.06 & 1 & 5 & 0.01 \\
\hline \multicolumn{6}{|l|}{ Principles: } \\
\hline 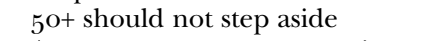 & $3 \cdot 54$ & 1.04 & 1 & 5 & 0.01 \\
\hline Age norm: too young to retire & 57.62 & 4.91 & 18 & 70 & 0.06 \\
\hline Age norm: too old to work & $66.3^{2}$ & 5.14 & 35 & 100 & 0.08 \\
\hline \multicolumn{6}{|l|}{ Pressures: } \\
\hline Influence of trade unions & 2.70 & 1.29 & 1 & 5 & 0.08 \\
\hline Multinational & 0.17 & 0.37 & o & 1 & 0.10 \\
\hline Contact with $5^{\mathrm{O}+}$ & 4.57 & 0.98 & 1 & 5 & 0.02 \\
\hline \multicolumn{6}{|l|}{ Organisation characteristics: } \\
\hline Country: Germany & 0.16 & - & o & 1 & 0.00 \\
\hline Country: Denmark & 0.11 & - & o & 1 & 0.00 \\
\hline Country: France & 0.09 & - & o & 1 & 0.00 \\
\hline Country: Italy & 0.14 & - & o & 1 & 0.00 \\
\hline Country: The Netherlands & 0.20 & - & o & 1 & 0.00 \\
\hline Country: Poland & 0.19 & - & o & 1 & 0.00 \\
\hline Country: Sweden & 0.10 & - & o & 1 & 0.00 \\
\hline $\begin{array}{l}\text { Sector: industries and } \\
\text { construction }\end{array}$ & 0.33 & - & o & 1 & 0.01 \\
\hline Sector: services and trade & 0.33 & - & o & 1 & 0.01 \\
\hline Sector: public & 0.33 & - & o & 1 & 0.01 \\
\hline$\%$ female workers & 0.43 & 0.28 & o & 1 & 0.03 \\
\hline$\%$ part-time workers & 0.18 & 0.23 & o & 1 & 0.02 \\
\hline$\%$ high-skilled workers & 0.26 & 0.29 & o & 1 & 0.02 \\
\hline$\%$ unskilled workers & 0.24 & 0.29 & o & 1 & 0.02 \\
\hline$\%$ 5o+ workers: expected growth & 0.23 & - & o & 1 & 0.02 \\
\hline $\begin{array}{l}\% 5^{\mathrm{O}+} \text { workers: expected } \\
\text { contraction }\end{array}$ & 0.23 & - & o & 1 & 0.02 \\
\hline $\begin{array}{l}\% 5^{\mathrm{O}+} \text { workers: no change } \\
\text { expected }\end{array}$ & 0.54 & - & o & 1 & 0.02 \\
\hline \multicolumn{6}{|l|}{ Respondent characteristics: } \\
\hline Function: $\mathrm{CEO} / \mathrm{CFO}$ & 0.30 & - & o & 1 & 0.04 \\
\hline Function: head of department & 0.09 & - & o & 1 & 0.04 \\
\hline Function: general manager & 0.15 & - & o & 1 & 0.04 \\
\hline $\begin{array}{l}\text { Function: HR manager/HR } \\
\text { officer }\end{array}$ & 0.27 & - & o & 1 & 0.04 \\
\hline Function: administrator & 0.05 & - & o & 1 & 0.04 \\
\hline Function: other & 0.13 & - & $\mathrm{o}$ & 1 & 0.04 \\
\hline Job requires academic degree & 0.63 & - & o & 1 & 0.01 \\
\hline
\end{tabular}


T A B LE 2. (Cont.)

\begin{tabular}{lccccc}
\hline Variable & Mean & SD & Minimum & Maximum & $\begin{array}{l}\text { Missing } \\
(\%)\end{array}$ \\
\hline Age & 46.23 & 9.86 & 18 & 78 & 0.01 \\
Female & 0.47 & - & 0 & 1 & 0.00 \\
\hline
\end{tabular}

Notes: The means and standard deviations are mostly identical and never more than 3 per cent different from the imputed statistics. SD: standard deviation. CEO/CFO: Chief Executive Officer/Chief Financial Officer. HR: human resources.

2011; De Grip, Fouarge and Montizaan 2015; Fleischmann, Koster and Schippers 2015; Van Dalen, Henkens and Schippers 2010a; Ybema, Geuskens and Oude Hengel 2009).

In Table 3, results are presented for the models predicting the phasing out and activating strategies. In terms of adjusted $R^{2}$, our models are slightly better at predicting the phasing out strategy ( $31 \%$ explained variance) than the activating strategy ( $25 \%$ explained variance).

The top section of Table 3 shows the estimations for the profit variables. For phasing out, the net benefits of older workers to the organisation aspect of the profit hypothesis is confirmed: seniority wages and productivity loss make phasing out more prominent, although other labour costs do not matter. The substitutability items are not all as predicted: expected personnel growth indeed has a negative effect on phasing out, but surprisingly, recruitment problems and organisation knowledge intensity have a significant positive effect on phasing out. The positive effect for organisation knowledge intensity may be explained by the distinction between firmspecific knowledge intensity and general, innovative knowledge intensity. An organisation in which firm-specific knowledge intensity is high probably relies more on older workers, and would be associated with low intensity of phasing out. An organisation in which general, innovative knowledge intensity is high would favour younger workers, and would be associated with high intensity of phasing out. Our measure of organisation knowledge intensity does not distinguish between general and firm-specific knowledge but captures both aspects; the positive effect may reflect that general, innovative knowledge has a greater influence. The feasibility part of the profit hypothesis is not supported: a greater proportion of older workers has a positive effect on phasing out policy implementation (since marginal costs become lower), and the squared percentage has a negative effect (since departmental functioning is threatened if the policies apply to too many workers). However, the number of employees has no significant effect, and whether it is a better investment to train younger workers has a small negative (rather than positive) effect. Hypothesis 1 a therefore yields a 
TA B LE 3. Pooled results of ordinary least squares regression on fully imputed data-set

\begin{tabular}{|c|c|c|c|c|}
\hline \multirow[t]{2}{*}{ Dependent variable } & \multicolumn{2}{|c|}{ Phasing out } & \multicolumn{2}{|c|}{ Activating } \\
\hline & Estimate & $\mathrm{SE}$ & Estimate & $\mathrm{SE}$ \\
\hline Intercept & -0.71 & 0.39 & -1.81 & $0.4^{8^{* * *}}$ \\
\hline \multicolumn{5}{|l|}{ Profit: } \\
\hline Seniority wages & 0.09 & $0.02 * * *$ & 0.04 & 0.03 \\
\hline Ageing increases labour costs & -0.01 & 0.03 & 0.04 & 0.04 \\
\hline Ageing increases productivity & -0.11 & $0.03 * * *$ & -0.05 & 0.03 \\
\hline Knowledge intensity & 0.07 & $0.02 * * *$ & 0.21 & $0.02 * * *$ \\
\hline Expected size: growth & -0.10 & $0.04 *$ & -0.07 & 0.05 \\
\hline Expected size: contraction & -0.08 & 0.05 & 0.09 & 0.06 \\
\hline \multicolumn{5}{|l|}{ Expected size: stays the same (Ref.) } \\
\hline Recruitment problems & 0.07 & $0.03^{*}$ & 0.17 & $0.04^{* * *}$ \\
\hline Number of employees & 0.00 & 0.00 & 0.00 & $0.00^{* * * *}$ \\
\hline$\% 5^{\mathrm{O}+\text { workers }}$ & 2.29 & $0.30^{* * *}$ & 1.82 & $0.35^{* * *}$ \\
\hline$\% 50+$ workers, squared & -2.28 & $0.40^{* * * *}$ & -2.11 & $0.45^{* * * *}$ \\
\hline Better investment to train $5^{0-}$ & -0.04 & $0.02 *$ & -0.11 & $0.02 * * *$ \\
\hline \multicolumn{5}{|l|}{ Principles: } \\
\hline $5^{\mathrm{O}+}$ should not step aside & -0.03 & 0.02 & 0.07 & $0.02 * *$ \\
\hline Age norm: too young to retire & 0.00 & 0.00 & -0.01 & 0.01 \\
\hline Age norm: too old to work & 0.00 & 0.00 & 0.02 & $0.00 * * *$ \\
\hline \multicolumn{5}{|l|}{ Pressures: } \\
\hline Influence of trade unions & 0.13 & $0.01 * * *$ & 0.08 & $0.02 * * *$ \\
\hline Multinational & 0.09 & 0.05 & 0.33 & $0.06^{* * * *}$ \\
\hline Contact with $5^{\mathrm{O}}+$ workers & 0.06 & $0.02 * *$ & 0.09 & $0.02 * * *$ \\
\hline \multicolumn{5}{|l|}{ Organisation characteristics: } \\
\hline Country: Germany & 0.21 & $0.07^{* *}$ & -0.20 & 0.10 \\
\hline Country: Denmark & 0.57 & $0.08 * * *$ & -0.07 & 0.22 \\
\hline Country: France & -0.16 & 0.11 & 0.42 & 0.22 \\
\hline Country: Italy & $-0.5^{6}$ & $0.08 * * *$ & -0.99 & $0.10^{* * *}$ \\
\hline Country: Netherlands & 1.32 & $0.08 * * *$ & -0.11 & 0.09 \\
\hline Country: Sweden & 0.15 & 0.09 & 0.30 & $0.10^{* * *}$ \\
\hline \multicolumn{5}{|l|}{ Country: Poland (Ref.) } \\
\hline Sector: services and trade & -0.05 & 0.05 & 0.03 & 0.06 \\
\hline Sector: public & 0.13 & $0.06^{*}$ & 0.16 & $0.06 *$ \\
\hline \multicolumn{5}{|c|}{ Sector: industries and construction (Ref.) } \\
\hline$\%$ female workers & -0.08 & 0.08 & 0.07 & 0.10 \\
\hline$\%$ part-time workers & 0.06 & 0.10 & 0.06 & 0.12 \\
\hline$\%$ high-skilled workers & 0.17 & $0.07^{*}$ & 0.15 & 0.08 \\
\hline$\%$ unskilled workers & -0.13 & 0.06 & -0.22 & $0.08 * *$ \\
\hline$\% 5^{\mathrm{O}}+$ workers: expected growth & -0.04 & 0.06 & 0.02 & 0.07 \\
\hline$\%$ 50+ workers: expected decrease & 0.02 & 0.06 & 0.19 & $0.07^{* *}$ \\
\hline$\%$ 5o+ workers: no change expected & & & & \\
\hline \multicolumn{5}{|l|}{ Respondent characteristics: } \\
\hline Function: head of department & 0.12 & 0.06 & 0.00 & 0.08 \\
\hline Function: general manager & 0.23 & $0.06 * * *$ & 0.00 & 0.07 \\
\hline Function: HR manager/HR officer & 0.33 & $0.05 * * *$ & 0.44 & $0.06^{* * * *}$ \\
\hline Function: administrator & 0.13 & 0.08 & 0.14 & 0.10 \\
\hline & 0.27 & $0.07 * * *$ & 0.17 & 0.09 \\
\hline \multicolumn{5}{|l|}{ Function: CEO/CFO (Ref.) } \\
\hline Job needs academic degree & 0.14 & $0.04^{* * *}$ & 0.30 & $0.05^{* * *}$ \\
\hline Age & 0.00 & 0.00 & 0.01 & $0.00^{* *}$ \\
\hline
\end{tabular}


T A в LE 3. (Cont.)

\begin{tabular}{|c|c|c|c|c|}
\hline \multirow[t]{2}{*}{ Dependent variable } & \multicolumn{2}{|c|}{ Phasing out } & \multicolumn{2}{|c|}{ Activating } \\
\hline & Estimate & SE & Estimate & $\mathrm{SE}$ \\
\hline $\begin{array}{l}\text { Female } \\
\text { Adjusted } R^{2}\end{array}$ & $\begin{array}{r}-0.03 \\
0.32\end{array}$ & 0.04 & $\begin{array}{r}-0.07 \\
0.25\end{array}$ & 0.05 \\
\hline
\end{tabular}

Notes: $\mathrm{N}=5,410$. Values are unstandardised coefficients. Imputations $=15$, iterations $=30 . \mathrm{SE}$ : standard error. Ref.: reference category. HR: human resources. CEO/CFO: Chief Executive Officer/Chief Financial Officer.

Significance levels: $* p<0.05, * * p<0.01, * * * p<0.001$, two-sided tests.

mixed result. For activating, no variables measuring net benefits of older workers to the organisation have any effect. The substitutability items also support our theoretical expectations: expected personnel growth or contraction has no effect on activating, but recruitment problems and organisation knowledge intensity both have substantial positive effects. All feasibility items perform as hypothesised: the proportion of older workers has a positive effect and its square a negative effect, supporting a curvilinear relationship; the number of employees has a positive effect as well, and when it is considered to be a better investment to train younger rather than older workers, the effect is negative. Hypothesis $1 \mathrm{~b}$ thus also yields a mixed result.

Age norms have no effect on the phasing out strategy, thus contradicting Hypothesis 2a. Two of the three age norms have a positive effect on activating. Believing older workers should not step aside has the expected positive effect on the intensity of the activating strategy. While the lower-bound retirement age norm has no effect, the more frequently used upperbound retirement age norm is also positively associated with strengthening the link between workers and their work. This supports Hypothesis $2 b$.

The phasing out strategy is positively associated with the informal pressure from contact with older workers and the formal pressure of trade unions; the formal pressure of a foreign headquarters has no significant effect. This supports Hypothesis 3a. For activating, all three pressures have the hypothesised positive effect, supporting Hypothesis 3 b. External actors can indeed stimulate organisations to implement age-adaptation policies, both for phasing out and activating.

The bottom sections of Table 3 contain the control variables. In models including only country and sector (not reported here), these variables have substantial effects. Compared to Poland (the reference country), the Netherlands scores particularly high on phasing out, and Italy particularly low on activating. In the reported models, country and sector differences are much smaller or disappear. This suggests that their effects are mediated by other firm properties included in these models. In line with previous 
research, the composition variables show mixed results. The respondent variables show positive significant effects for functions other than that of $\mathrm{CEO}$, and which require an academic degree. This probably reflects a greater policy awareness among better-educated and more directly involved personnel.

\section{Sensitivity analyses}

Several sensitivity analyses show that the findings are robust: in virtually all cases, adding, removing or recoding (vectors of) variables did not substantially change the effects of the main theoretical variables. First, we truncated the age norms, as has been proposed in previous studies (Karpinska, Henkens and Schippers 2013a; Radl 2012), to lie between $5^{\mathrm{O}}$ and 8o. This did not affect phasing out, and yielded moderately larger effect sizes for the impact of age norms on activating. Second, we replaced the personnel size with its logarithm, as firm size is right-skewed. For phasing out, this made the difference between insignificance and significance at $p<0.001$. This accorded with studies in which firm size had a substantial effect when it was modelled as a logarithm (Fleischmann, Koster and Schippers 2015; Oude Mulders, Henkens and Schippers 2017) or trichotomy (Jensen and Møberg 2012), and was insignificant when modelled in a linear way (Van Dalen, Henkens and Wang 2015). This increase came at the expense of the other policy feasibility items, thus underlining their relationship: the effects of proportion of older workers and its squared counterpart were almost halved, and are significant at $p<0.05$ rather than $p<0.001$. Additionally, the lower retirement age norm and expected personnel shrinkage became significant at $p<0.05$. Third, we used an eight-item scale for phasing out rather than the five-item scale, adding items on extra leave, demotion and an age limit for irregular work. Theoretically and empirically, these items are clearly associated with phasing out, yet they are borderline cases concerning Mokken and reliability analyses scores. In terms of model fit and $p$-values, the eight-item model performed slightly better than the model in Table 3 , but this does not affect our conclusions. Fourth, it could be argued that substitutability of older workers is particularly influential on the phasing out strategy in a context of low net benefits of older workers to the organisation; if net benefits to the organisation are high, the incentive to replace older workers with younger workers is lower. Therefore, a positive interaction between low net benefits of older workers to the organisation and high substitutability could be expected. However, the only interaction between these items that is significant (at $p<0.05$ ) is between organisation knowledge intensity and seniority wages $(p=0.02)$. Surprisingly, the interaction is negative: 
the impact of substitutability is smaller for organisations with strikingly high seniority wages.

\section{Discussion and conclusion}

Older workers constitute an increasing proportion of the working population, but are often peripheral to general personnel policies. For that reason, this study analysed which organisations implement specific old-age adaptation policies. We categorised policies into two dimensions: phasing out and activating (Bal, Kooij and De Jong 2013; Fleischmann, Koster and Schippers 2015; Kotiso and Lokhorst 2009; Remery et al. 2003; Van Dalen, Henkens and Schippers 2010b; Ybema, Geuskens and Oude Hengel 2oog). This paper is the first to verify these dimensions empirically and use them to test the influence of profit, principle and pressure considerations. For these purposes, we made use of the ASPA survey (2009), containing 5,410 organisations in seven European countries.

Our findings showed that to understand old-age adaptation policies we need to move beyond profit considerations, which have been the main focus of prior research (Conen, Henkens and Schippers 2012; Fleischmann, Koster and Schippers 2015). We studied three aspects of profit considerations: feasibility of age adaptation policies, net benefits of older workers to the organisation and substitutability of older workers. We found that the feasibility of age adaptation policies influenced both phasing out and activating. Yet, the influence of organisation knowledge intensity as an indicator of substitutability was different than expected. We assumed organisation knowledge intensity primarily captured firm-specific knowledge, which would negatively influence phasing out older workers and replacing them with younger workers. Instead, the association was positive, which indicates that organisations wish to bring in general, innovative knowledge by hiring new workers, when knowledge intensity is high. The net benefits of older workers to the organisation only influenced phasing out and the substitutability of older workers only influenced activating. Apparently, therefore, profit considerations are only part of the reason organisations implement age adaptation policies. These results imply that old-age adaptation policies cannot be fully understood if the different motivations for implementing them are not modelled. Additionally, the three-aspect approach holds two other advantages. Most importantly, the pattern among variables is more readily interpretable than for papers studying several predictors in their own right: more abstract conclusions can be drawn (Jensen and Møberg 2012; Van Dalen, Henkens and Wang 2015). Additionally, testing theories at the level of individual variables runs a greater risk of finding 
false negatives. For example, only analysing the pressure from foreign headquarters would have led us to conclude that pressures do not induce phasing out, whereas we currently conclude that pressures are relevant.

Our study showed that age norms (managerial principles) and external pressures (particularly unions) are also relevant. Implementing policies can be motivated by the desire to follow managerial principles, in line with previous research on the influence of age norms on managerial behaviour (Karpinska, Henkens and Schippers 2013a, 2013b; Oude Mulders, Henkens and Schippers 2017; Oude Mulders et al. 2014). Although age norms supporting working longer are indeed associated with an activating strategy, age norms did not predict the phasing out strategy. Possibly, phasing out policies are compatible with both the belief older workers should retire, and the belief older workers should continue working in a 'cooling down' period. Our data also suggest that external pressures on managers can contribute to implementation of old-age adaptation policies, either through informal contact with their employees, trade unions or foreign headquarters 'exporting' their HR policies. This reflects previous findings on the importance of external actors for policy implementation (Armstrong-Stassen and Cattaneo 2010; Björkman and Lervik 2007; Schaeps 2002).

The relative importance of principles and pressures vis-à-vis profit is particularly striking for the activating strategy. The fact that profit and principle considerations work differently for phasing out and activating substantiates the need for studying these dimensions separately: net benefits of older workers to the organisation only had an impact on phasing out, while substitutability and principles only affected activating. Studying the dimensions jointly (Fleischmann, Koster and Schippers 2015) would have led us (wrongly) to conclude that age norms do not matter, and that net benefits of older workers to the organisation and substitutability matter for both strategies, while net benefits of older workers to the organisation are less central than expected.

Since a broad theoretical array of factors can influence age adaptation policies, governments trying to increase implementation of activating policies would benefit from not restricting themselves to the consideration of financial incentives, which are found to have limited effects (Fleischmann and Koster 2017). Future governmental initiatives should also aim to use rules and instruments to influence age norms and pressures. For instance, it has repeatedly been found that after governments had changed the pension regulations, retirement age norms converged towards the new legal pension age (Kohli 2007; Radl 2012).

Several limitations to this study should be mentioned. First, the ASPA data were collected in 2009. Recent studies have suggested both an increase in old-age adaptation policies due to higher salience (Fleischmann, Koster 
and Schippers 2015) and a decrease, due to shrinking HR budgets as a result of the economic crisis (De Grip, Fouarge and Montizaan 2015; Frerichs et al. 2012 ; Jensen and Møberg 2012). It would be informative to test our hypotheses with more recent data; although we have no reason to believe that the mechanisms tested in this paper have changed recently. Second, the two 'strategies' are not necessarily implemented as consciously as the word implies. Organisations often introduce HR policies separately rather than in a comprehensive package (Remery et al. 2003). Nevertheless, the policies in each strategy show a strong empirical and theoretical relation, and the strategies can successfully be explained by our models, which supports our studying the policies jointly. Third, since the data are cross-sectional rather than longitudinal, the possibilities of drawing causal inferences between implementation and organisational characteristics are limited. It is, however, theoretically implausible that the correlational evidence should be interpreted inversely, as the presence of employability practices is not likely to influence union strength or scarcity on the labour market. Fourth, our focus on theoretical mechanisms meant we had to leave country differences outside the scope of this study. Although prior research indicated that organisations are the most important actors, not governments (Fleischmann, Koster and Schippers 2015; Loretto and White 2006a; Remery et al. 2003), future studies are invited to study this topic in a cross-national setting, focusing on factors like labour market and pension characteristics.

With increasing retirement ages, governments might consider preferring activating policies over phasing out policies. Knowing what drives the implementation of either policy is a good starting point for making such a decision.

\section{Acknowledgements}

The authors are thankful for the useful comments on earlier drafts of this paper made by Maria Fleischmann, Mark Visser, Marcel Lubbers and two anonymous reviewers. The research leading to these results has received funding from the European Research Council under the European Union's Seventh Framework Programme (FP/2007-2013)/ERC Grant Agreement number 340045 .

\section{NOTE}

1 The item on transitional retirement is based on the question 'Do employees in your establishment usually reduce their working hours before they fully retire?'

\section{References}

Armstrong-Stassen, M. 2008a. Human resource practices for mature workers - and why aren't employers using them? Asia Pacific Journal of Human Resources, 46, 3, 334-52. 
Armstrong-Stassen, M. 2008b. Organisational practices and the post-retirement employment experience of older workers. Human Resource Management Journal, 18, $1,36-53$.

Armstrong-Stassen, M. and Cattaneo, J. 2010. The effect of downsizing on organizational practices targeting older workers. Journal of Management Development, 29, 4, 344-63.

Bal, M. P., Kooij, D. T. A. M. and De Jong, S. B. 2013. How do developmental and accommodative HRM enhance employee engagement and commitment? The role of psychological contract and SOC strategies. Journal of Management Studies, $\mathbf{5}^{\mathbf{0}}, 4,545^{-72 .}$

Berman, E. M., West, J. P. and Richter, M. N., Jr 2002. Workplace relations: friendship patterns and consequences (according to managers). Public Administration Review, 62, 2, 21 7-30.

Billari, F. C. and Liefbroer, A. C. 2007. Should I stay or should I go? The impact of age norms on leaving home. Demography, 44, 1, 181-98.

Björkman, I. and Lervik, J.E. 2007. Transferring HRM practices within multinational corporations. Human Resource Management Journal, 17, 4, 320-35.

Conen, W. S., Henkens, K. and Schippers, J. 2011. Are employers changing their behavior toward older workers? An analysis of employers' surveys 2000-2009. Journal of Aging and Social Policy, 23, 2, 141-58.

Conen, W. S., Henkens, K. and Schippers, J. 201 2. Employers' attitudes and actions towards the extension of working lives in Europe. International Journal of Manpower, 33, 6, 648-65.

Conen, W. S., Van Dalen, H. P. and Henkens, K. 2012. Ageing and employers' perceptions of labour costs and productivity: a survey among European employers. International Journal of Manpower, 33, 6, 629-47.

Conen, W. S., Van Dalen, H. P., Henkens, K. and Schippers, J. 2011 . Activating senior potential in ageing Europe: an employers' perspective. ASPA integrative report. Netherlands Interdisciplinary Demographic Institute, The Hague.

De Grip, A., Fouarge, D. and Montizaan, R. 2015. Goede inzetbaarheid oudere medewerkers vereist beter HR-beleid. Netspar, Tilburg, The Netherlands. Available online at: http:/ / www.netspar.wgo2.webgenerator.nl/files/documenten/pdfs $\%$ 2oen\% 2odocs/Brief/Brief\% 204/Netspar\% 20Brief\% 204.pdf [22 September 2015 ].

De Vries, S., Gründemann, R. and Van Vuuren, T. 2001. Employability policy in Dutch organizations. International Journal of Human Resource Management, 1 2, 7 , $1193^{-202 .}$

Ebbinghaus, B. 2006. Reforming Early Retirement in Europe, Japan and the USA. Oxford University Press, Oxford.

Fleischmann, M. and Koster, F. 2017. Older workers and employer-provided training in the Netherlands: a vignette study. Ageing $\mathcal{E}$ Society. Published online, 12 April 2017, doi:10.1017/So144686X17000356.

Fleischmann, M., Koster, F., Dykstra, P. and Schippers, J. 2014. Hello pension, goodbye tension? The impact of work and institutions on older workers' labor market participation in Europe. International Journal of Ageing and Later Life, 8, 2, $1-35$.

Fleischmann, M., Koster, F. and Schippers, J. 2015. Nothing ventured, nothing gained! How and under which conditions employers provide employability-enhancing practices to their older workers. International Journal of Human Resource Management, 26, 22, 2908-25.

Frerichs, F., Lindley, R. M., Aleksandrowicz, P., Baldauf, B. and Galloway, S. 2012. Active ageing in organisations: a case study approach. International Journal of Manpower, 33, 6, 666-84. 
Henkens, K. 2005. Stereotyping older workers and retirement: the managers' point of view. Canadian Journal on Aging/La Revue canadienne du vieillissement, 24, $4,353-66$.

Hewitt, S. D. 2009. Tackling psychological disengagement in older workers. Industrial and Commercial Training, 41, 2, 87-91.

Jensen, P. H. and Møberg, R. 201 2. Age management in Danish companies: what, how, and how much? Nordic Journal of Working Life Studies, 2, 3, 49-66.

Josten, E. and Vlasblom, J. D. 2015. Beïnvloeden ontziemaatregelen de houding van werkgevers ten opzichte van ouderen? Tijdschrift voor Arbeidsuraagstukken, 3, 31, 314-29.

Kalleberg, A. L. 2009. Precarious work, insecure workers: employment relations in transition. American Sociological Review, 74, 1, 1-22.

Karpinska, K., Henkens, K. and Schippers, J. 2011 . The recruitment of early retirees: a vignette study of the factors that affect managers' decisions. Ageing $\mathcal{E}$ 'Society, $\mathbf{3 1}$, $4,570-89$.

Karpinska, K., Henkens, K. and Schippers, J. 2013a. Hiring retirees: impact of age norms and stereotypes. Journal of Managerial Psychology, 28, 7/8, 886-9o6.

Karpinska, K., Henkens, K. and Schippers, J. 2013 b. Retention of older workers: impact of managers' age norms and stereotypes. European Sociological Review, 29, $6,1323-35$.

Kluge, A. and Krings, F. 2008. Attitudes towards older workers and Human Resource practices. Swiss Journal of Psychology, 67, 1, 61-4.

Kohli, M. 2007. The institutionalization of the life course: looking back to look ahead. Research in Human Development, 4, 3/4, 253-71.

Kotiso, A. and Lokhorst, B. 2009. Van ontzien naar duurzaam ontwikkelen. Alternatieven voor seniorenregelingen in CAO's. Expertisecentrum LEEFtijd, Utrecht, The Netherlands. Available online at: https://www.blikopwerk.nl/doc/media/Eindrapport-Vanontzien-naar-duurzaam-ontwikkeling.pdf [29 September 2015].

Lancee, B. and Radl, J. 201 2. Social connectedness and the transition from work to retirement. Journals of Gerontology: Psychological Sciences and Social Sciences, $\mathbf{6}_{\mathbf{7}} \mathbf{B}, 4$, $481-90$.

Liefbroer, A. C. and Billari, F. C. 2010. Bringing norms back in: a theoretical and empirical discussion of their importance for understanding demographic behaviour. Population, Space and Place, 16, 4, 287-305.

Loretto, W. and White, P. 20o6 $a$. Employers' attitudes, practices and policies towards older workers. Human Resource Management Journal, 16, 3, 313-30.

Loretto, W. and White, P. 20o6b. Population ageing and older workers: employers' perceptions, attitudes and policies. Population, Space and Place, 12, 5, 341-52.

Lyon, P., Hallier, J. and Glover, I. 1998. Divestment of investment? The contradictions of HRM in relation to older employees. Human Resource Management Journal, 8, 1, 56-66.

McNair, S., Flynn, M. and Dutton, N. 2007. Employer Responses to an Ageing Workforce: A Qualitative Study. Department for Work and Pensions, Leeds, UK.

Mirvis, P. H. 1997. Human Resource Management: leaders, laggards, and followers. The Academy of Management Executive, 11, 2, 43-56.

Neugarten, B. L., Moore, J. W. and Lowe, J. C. 1965 . Age norms, age constraints, and adult socialization. American Journal of Sociology, 7o, 6, $710-7$.

O'Donnell, S. W. 200o. Managing foreign subsidiaries: agents of headquarters, or an interdependent network? Strategic Management Journal, 21, 5, 525-48.

Oude Mulders, J., Henkens, K. and Schippers, J. 201 7. European top managers' agerelated workplace norms and their organizations' recruitment and retention practices regarding older workers. The Gerontologist, 57, 5, 857-66. 
Oude Mulders, J., Van Dalen, H. P., Henkens, K. and Schippers, J. 2014. How likely are employers to rehire older workers after mandatory retirement? A vignette study among managers. De Economist, 162, 4, 41 5-31.

Perek-Bialas, J. and Turek, K. 2012. Organisation-level policy towards older workers in Poland. International Journal of Social Welfare, 21, s1, 101-16.

Principi, A., Fabbietti, P. and Lamura, G. 2015 . Perceived qualities of older workers and age management in companies: does the age of HR managers matter? Personnel Review, 44, 5, 801-10.

Radl, J. 2012. Too old to work, or too young to retire? The pervasiveness of age norms in Western Europe. Work, Employment $\mathcal{E}^{2}$ Society, 26, 5, 755-71.

Remery, C., Henkens, K., Schippers, J. and Ekamper, P. 2003. Managing an aging workforce and a tight labor market: views held by Dutch employers. Population Research and Policy Review, 22, 1, 21-40.

Rosenzweig, P. M. and Nohria, N. 1994. Influences on Human Resource Management practices in multinational corporations. Journal of International Business Studies, 25, 2, 229-51.

Schaeps, M.J. M. 2002. Levensloopbestendige afspraken. Een overzicht van afspraken samengesteld op basis van verschillende door de Arbeidsinspectie uitgevoerde onderzoeken. The Hague, The Netherlands. Available online at: http://cao.minszw.nl/pdf/35/ 2003/35_2003_3_3485.pdf [Accessed 25 September 2015].

Shore, L. M., Cleveland, J. N. and Goldberg, C. B. 2003. Work attitudes and decisions as a function of manager age and employee age. Journal of A pplied Psychology, 88, 3, 529-37.

Steinberg, M., Donald, K., Najman, J. and Skerman, H. 1996. Attitudes of employees and employers towards older workers in a climate of anti-discrimination. Australasian Journal on Ageing, 15, 4, 154-8.

Streb, C. K., Voelpel, S. C. and Leibold, M. 2008. Managing the aging workforce: status quo and implications for the advancement of theory and practice. European Management Journal, 26, 1, 1-10.

Taylor, P. and Walker, A. 1998. Employers and older workers: attitudes and employment practices. Ageing EO Society, 18, 6, 641-58.

Van Buuren, S. and Groothuis-Oudshoorn, K. 201 1. MICE: multivariate imputation by chained equations in R. Journal of Statistical Software, 45, 3, 1-67.

Van Dalen, H. P., Henkens, K. and Schippers, J. 2007. Oudere werknemers door de lens van de werkgever. Report 74. Netherlands Interdisciplinary Demographic Institute, The Hague, The Netherlands.

Van Dalen, H. P., Henkens, K. and Schippers, J. $2010 a$. How do employers cope with an ageing workforce? Demographic Research, 22, 32, $1015^{-36 .}$

Van Dalen, H. P., Henkens, K. and Schippers, J. $2010 \mathrm{o}$. Productivity of older workers: perceptions of employers and employees. Population and Development Review, 36, 2, 309-3o.

Van Dalen, H. P., Henkens, K. and Wang, M. 2015. Recharging or retiring older workers? Uncovering the age-based strategies of European employers. The Gerontologist, 55, 5, 814-24.

Verma, A. 2005. What do unions do to the workplace? Union effects on management and HRM policies. Journal of Labor Research, 26, 3, 41 $5^{-49}$.

Vickerstaff, S. and Cox, J. 2005. Retirement and risk: the individualisation of retirement experiences? The Sociological Review, 53, 1, 77-95.

Vink, G., Lazendic, G. and Van Buuren, S. 2015 . Partitioned predictive mean matching as a multilevel imputation technique. Psychological Test and Assessment Modeling, $\mathbf{5 7}, 4,577-94$.

Vink, G. and Van Buuren, S. 2013. Multiple imputation of squared terms. Sociological Methods Ev Research, $\mathbf{4 2}^{2}, 4,59^{8-607 .}$ 
950 Jelle Lössbroek et al.

Visser, J. 2006. Union membership statistics in 24 countries. Monthly Labor Review, 129, $1,38-49$.

Walker, A. 2006. Active ageing in employment: its meaning and potential. Asia-Pacific Review, 13, 1, 78-93.

Ybema, J. F., Geuskens, G. and Oude Hengel, K. 2009. Oudere werknemers en langer doorwerken: Secundaire analyses van de NEA, het NEA-cohortonderzoek en de WEA. TNO, Hoofddorp, The Netherlands.

Accepted 26 October 2017 ; first published online I4 December 2017

Address for correspondence:

Jelle Lössbroek,

Department of Sociology,

Utrecht University,

Padualaan 14, 3584 CH,

Utrecht, The Netherlands

E-mail: j.j.h.lossbroek@uu.nl 